\title{
Performance Characterization of Polycrystalline Silicon Photovoltaic Modules Installed in Kumasi, Ghana
}

\author{
G. Takyi* \\ Department of Mechanical Engineering Kwame Nkrumah University of Science and Technology, Kumasi, GHANA.
}

\begin{abstract}
The focus of this study is on the assessment of the performance of 14 polycrystalline silicon PV modules installed in Kumasi, Ghana after 22 years of field exposure. Visual inspection was carried out to ascertain any observable defects. Current-Voltage performance data was taken using a non-invasive characterization technique able to predict performance at standard test conditions (using TRI-KA and TRI-SEN) followed by Infrared (IR) Imaging tests. The results of the I-V tests showed average Pmax degradation rate of $1.38 \% / y r$ for all 14 modules. This is higher than the acceptable limit of (0.7-1.0\%/year). In terms of the individual modules, M1 recorded the worst Pmax rate of degradation of $1.74 \% / y$, and the lowest values for efficiency and fill factor. This is consistent with the IR images and temperature difference that were recorded in the IR tests. A higher temperature difference of $25^{\circ} \mathrm{C}$ was recorded indicating the presence of a hot spot and a defective cell which was confirmed by the hue white colour observed in the IR test. Power Performance Factor (PPF) range of 61.8-76.5\% was recorded which is below the limit of $80 \%$ often quoted in warranty statements. The drops in PPF indicate that the modules have degraded.
\end{abstract}

Keywords: performance degradation, infra-red, fill factor, efficiency

\section{INTRODUCTION}

There has been influx of various types of photovoltaic modules from different countries in Europe, Asia and USA into Africa especially, Ghana due to the recent interest in the use of photovoltaic systems. Testing the performance of those modules have thus become imperative. Some countries have mastered the art of producing highquality solar cells, as a result of technological advances, while others have not. Consequently, due to the inefficiency of manufacturing processes and the assembly of solar cells into modules, the theoretical performance parameters claimed by some manufacturers might not necessarily be the practical parameters. The solar PV market has experienced exponential growth over the last decade and global adoption has led to a number of studies on the design and performance of PV systems [1]. However, the efficiency of PV modules over time is becoming a major concern for stakeholders on the renewable energy market. Of great concern is the PV module degradation rate. The higher the degradation rate, the less the power production and the lower the future cash flows.

Important measures are being taken to track the output and handling of PV to reduce setbacks. Latest PV work focuses on achieving high utilization and optimal efficiency of photovoltaic systems

*Corresponding author (Tel: +233 203802 911)

Email address: gtakyi.soe@knust.edu.gh (G. Takyi)
[2]. PV modules are characterized by indoor standard test conditions (STCs) using an irradiance of $1000 \mathrm{~W} / \mathrm{m}^{2}$ from a simulation lamp and a temperature of $25^{\circ} \mathrm{C}$ at 1.5 absolute air mass (A.M) [3]. However, the outdoor output conditions do not automatically comply with the indoor STC. As a result, factory rated values are found to vary during their realistic usage due to changes in the sun's position, amount of solar radiation, cloud cover, module temperature and geographical location [4].

Most photovoltaic sizing and installations in different regions are carried out on the basis of the Standard Test Conditions, which are very different from the regional ambient conditions. A PV system's reliability and lifetime depends primarily on the energy performance of modules and their various modes of degradation. Research must therefore focus on the degradation of the PV modules. A review of different types of degradation have been presented in [5]. Corrosion and discoloration of PV modules encapsulant were predominant degradation modes that were identified. Temperature and humidity were also identified as the key factors that contributed to the degradation modes. Solar photovoltaic modules typically have a degradation rate between $0.7 \%$ $1.0 \%$ [6]. Most manufacturers offer the 25-year standard solar panel warranty with the meaning that power output after 25 years should not be less than $80 \%$ of the rated power. The best solar PV panel conversion efficiency is about $15-19 \%$. 
There is a lot of research designed to increase the percentage of power generation using one and two axes PV sun tracking technologies. In a study in Teipei involving the use of a single axis tracking system, total power generation increased by $25.4 \%$ [7]. The highest output currently obtained by solar PV panels is $26 \%$ [8].

A comparative study was carried out into the effect of a dual-axis solar tracking on power generation compared to a fixed panel in Turkey. The results showed a daily average gains of $29.3 \%$ in solar radiation and $34.6 \%$ in power generation for a particular day [9]. Experimental investigation on the effect of using two-axis sun-tracking systems under Jordanian climate was conducted [10]. It was determined that there was an increase of about $30-45 \%$ in the output power compared to the fixed PV system, for particular days.

A number of publications are available in the literature concerning solar PV applications in SSA. A study in [11] addressed the barriers facing solar PV energy systems development in most countries in Africa. The authors presented another study on twenty-nine (29) crystalline silicon modules deployed in grid-connected, batterycharging and water-pumping applications [12]. The modules, installed at six different locations in Ghana were aged between 6 and 32 years. Peak power (Pmax) losses ranged from $0.8 \% /$ year $6.5 \% / y e a r$ were reported. The Pmax losses were dominated by losses in fill factor (FF) and shortcircuit current (Isc). An experimental study was conducted into the effect of soiling on PV module performance using I-V and IR thermography tests [13]. The results indicated a four-fold reduction in power due to soiling effects. In a study by carried out by [14], the optical transmission of glass reduced by $26 \%$ due to dust accumulation. The effect of temperature on PV module performance in Ibadan, Nigeria was also investigated into [15]. The results showed that under water cooling conditions, the temperature decreased significantly leading to increase in Isc and maximum power. The study did not carry out detailed investigation into the cause of degradation. Most of the studies reported in the literature are not related to PV module long term degradation and reliability which is the focus of this work.

UV radiation is a significant cause of discoloration in materials leading to degradation. The cumulative UV radiation dose may be defined as the number of photons absorbed by the substance resulting in chemical change and degradation. The performance degradation of silicone encapsulated PV modules that are used for concentrator PV systems or space applications due to long term exposure to ultraviolet (UV) was addressed [16]. Different transparent silicones models (DC93-500 and Elastosil S690 and S695) were subjected to a time and wavelength UV test with a total accumulated dose of 10,000 equivalent sun hours. The results showed a correlation between the decrease in transmittance and the short circuit current. The amount of power obtainable from a solar cell is determined by the intensity of sunlight.
The higher the intensity of solar radiation, the higher the power obtained. The type and area of the material used to fabricate the solar cell also determines the amount of power obtained. Silicon solar cells can be fabricated from semiconductor materials in three ways: single crystal silicon, polycrystalline silicon and amorphous (non-crystalline) silicon. Amorphous silicon cells are generally of lower efficiency compared to crystalline silicon cells. The larger the area of the solar cell, the more the power obtainable from the solar cell. The wavelength of sunlight is another factor that affects the amount of power harnessed. The solar spectrum comprises three major regions: ultraviolet region $(\lambda<0.4 \mu \mathrm{m})$ constitutes $9 \%$ of irradiance, visible region $(0.4 \mu \mathrm{m}<\lambda<$ $0.7 \mu \mathrm{m}$ ) constitutes about $45 \%$ of irradiance, and infrared red region $(\lambda>0.7 \mu \mathrm{m})$ constitutes $46 \%$ irradiance [17]. Photodegradation caused by UV radiation is the main cause of degradation due to the exposure of materials to direct sunlight. UV radiation is a major cause of discoloration in materials leading to degradation. For PV module, this degradation is reflected in the change in the transmittance of the encapsulating module, which induces a decrease in the current-voltage characteristic of the PV module [16]. Recent studies including [18] have shown power degradation ranges of $0-2.1 \% / y r$ from defects related to busbar, $0-2.1 \% / y r$ due to cell interconnection ribbon related problems and 1.0-2.3\%/yr due to string interconnection related problems. Average degradation of 2.6\%/yr was recorded for EVA discoloration defects. In [19-21], the effect of discoloration was found to result in a loss of transmittance of the encapsulant EVA, leading to a reduction in the photocurrent density of the cell/module and subsequently culminating in a reduction in absorption of sunlight by the silicon cells and loss of power.

A lot of work has been carried out in the literature in the area of the performance of PV modules. There is however, limited data on the long-term performance of PV modules in the sub-Saharan Africa region and this study seeks to contribute to bridging that gap. The performance of field-aged crystalline Si based PV modules was measured in north Italy [22]. In that study, high performance losses $(>20 \%)$ were attributed to losses of the fill factor, caused by an increased series resistance. Losses $(<20 \%)$ which were considered as moderate performance losses were attributed to losses of the short-circuit current, caused by degradation of the optical properties. The long-term losses were determined to be between $0.2 \%$ and $1.0 \%$ per annum. This study seeks to determine the rate of degradation caused particularly, by the PV module temperature leading to hotspots, decrease in fill factor (FF) resulting from increased series resistance and decrease in efficiency. The study is part of a wider programme of work on the performance evaluation of modules installed in Ghana in Sub-Saharan Africa. 
Table 1: Materials and method used in the study.

\begin{tabular}{llll}
\hline Method & Material & Manufacturer (model) & country \\
\hline & 36 cells Polycrystalline PV module & ASE GmbH & Germany \\
Visual inspection & - & - & - \\
IV Curve tracing & Trika-Trisen & TRIKA & Netherlands \\
IR Thermal imaging & Fluke & Fluke (Ti400) & Germany \\
\hline
\end{tabular}

\subsection{Theory}

A solar module's output characteristics are calculated by parameters such as Pmax, Voc, Isc, FF, and efficiency of the cell that can be calculated by the I-V characteristics. The light generated current (I) is determined according to Eq. (1) [3].

$$
\begin{gathered}
I=I_{p h}-I_{o}\left[\exp ^{q V \ln k T}-1\right]-\frac{V-I R_{s}}{R_{s h}} \\
V_{o c}=\frac{n k T}{q}\left(\ln I_{s c}-\ln I_{o}\right)
\end{gathered}
$$

Where $I_{p h}$ is the photo current, $I_{o}$ is the dark saturation current, $q$ is the charge of an electron, $n$ is the diode quality factor and $R_{s}$ is the series resistance [23]. $V_{o c}$ (open circuit voltage), is the voltage determined when the terminals of the PV unit are isolated. It relates to the voltage that occurs when there is no current going through the cell. It is based on Eq. (2), where $k$ is the Boltzmann constant, $T$ is temperature, $I_{p h}$ (or $I_{s c}$ ) is the generated current, $q$ is charge of an electron and $I_{o}$ is the temperature dependent dark saturated current. The fill factor (FF) gives a measure of the quality of the cell and its determined according to Eq. (3). FF is between 0.7 and 0.8 for a good cell, and may be 0.4 for a poor one PV Education [24].

The fill factor is determined using Eq. (3).

$$
\begin{aligned}
F F & =\frac{P_{\max }}{V_{o c} \times I_{s c}} \\
& =\frac{I_{\max } \times V_{\max }}{V_{o c} \times I_{s c}}
\end{aligned}
$$

Efficiency $(\eta)$ is the ratio of the electrical output, Pout as opposed to the solar cell supply, Pin as shown in Eq. (4) [3].

$$
\begin{aligned}
\eta=\frac{P_{\text {out }}}{P_{\text {in }} \times I_{s c}} \rightarrow \eta_{\max } & =\frac{P_{\max }}{P_{\text {in }} \times I_{s c}} \\
& =\frac{V_{o c} \times I_{s c} \times F F}{I t \times A c}
\end{aligned}
$$

Where power in, $P_{\text {in }}=I t\left(\operatorname{Irradiance}\left(\mathrm{W} / \mathrm{m}^{2}\right)\right) \times A c$ (cross sectional area of solar cell $\left(\mathrm{m}^{2}\right)$ ). IV curve tracing is a tool used to evaluate the performance of a PV module or array, suitable for checking all possible PV module operating points or module strings. The electric power produced by the solar
PV cell or module is a function of the characteristics of the current (I) and voltage (V). A characteristic current versus voltage (I-V) curve is produced by measuring the relationship between current and voltage while varying the electrical load connected to the PV cell or module from open circuit to short circuit.

\section{MATERIALS AND METHODS}

This study seeks to characterize the performance of 14 polycrystalline PV modules with outdoor exposure of 22 years in Kumasi, Ghana on Latitude $6^{\circ} 40^{\prime \prime} \mathrm{N}$ and longitude $1^{\circ} 37^{\prime \prime} \mathrm{W}$ in SubSaharan Africa. The modules were rack mounted and installed on the roof of the Solar Energy Laboratory building, College of Engineering, Kwame Nkrumah University of Science and Technology at an angle of 12 degrees and currently not connected to the grid. Table 1 shows the methods, equipment and materials used in this study.

\subsection{Experimental}

The experiments carried out include:

Visual inspection

The 14 polycrystalline modules from the same manufacturer were physically inspected using the National Renewable Energy Laboratory's (NREL) Visual Inspection Checklist [23]. To determine the visual defects or failures, we visually examined the conditions of the modules.

\subsection{I-V Curve Tracing}

In this study, TRI-KA characteristics analyzer in conjunction with TRI-SEN sensing device were used for IV curve tracing. The TRI-KA characteristics analyzer measures and computes the following electrical parameters: short-circuit current, open-circuit voltage, I/V characteristic curve, STC characteristic curve, ideal characteristics curve of module manufacturer, and fill factor.

The TRI-SEN is used to measure the module level temperature, inclination angle and the global irradiation. This information is sent to the TRI-KA wirelessly to enable the extrapolation of the characteristic curve into STC curve (1000 $\mathrm{W} / \mathrm{m}^{2}$ irradiation, 1.5 Air Mass and temperature of, $25^{\circ} \mathrm{C}$ ). The TRISEN uses a monocrystalline silicon reference cell to measure irradiance. Eqs. (5) - (7) show the formulae used in computing the rate of degradations for $P_{m x}, I_{s} c, V_{o c}$ as reported in [6].

$$
P_{\max } \text { deg rate }=\frac{\left(P_{\max } \text { drop }\right)}{\text { years of operation (age) }}
$$




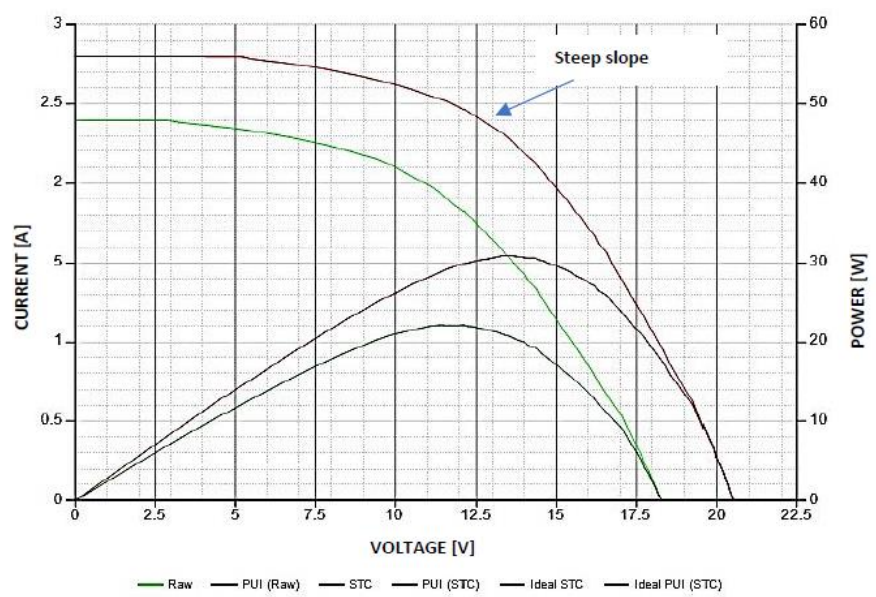

Figure 1: I-V curve for module 1.

$$
\begin{aligned}
& I_{s c} \text { deg rate }=\frac{I_{s c \text { drop }}}{\text { years of operation (age) }} \\
& V_{o c} \text { deg rate }=\frac{V_{o c \text { drop }}}{\text { years of operation (age) }}
\end{aligned}
$$

Where $P_{\text {maxdrop }}, I_{\text {scdrop }}$ and $V_{\text {ocdrop }}$ are the changes in power, short circuit current and open circuit voltage respectively.

\subsection{IR Imaging}

Hotspot is one of the most powerful indicators for diagnosing defective areas of a PV module. These are areas in which parts of the module have high temperatures. In this study, infrared tests were carried on the module surfaces using Fluke Corporation's thermal imager Ti400. This experiment examined the surfaces of all the cells of each module by moving the imager from cell to cell, repeating the test for all fourteen (14) modules. Each module was short-circuited prior to the test. This was done by observing the distribution of temperature over the PV module surface. The hottest and coolest temperature points were noted and recorded as well as the difference between them. Cells of modules with extreme variations in high temperatures indicate that the module is defective. Under the criteria specified by [25] and [26] for the infra-red test, modules that record a temperature difference below $10^{\circ} \mathrm{C}$ are considered as pass and those above $10^{\circ} \mathrm{C}$ are deemed to have failed the hot spot tests.

\section{RESULTS AND DISCUSSION}

This section presents the results of the various experiments carried out as well as discussions of the results and possible reasons for observed behaviour.

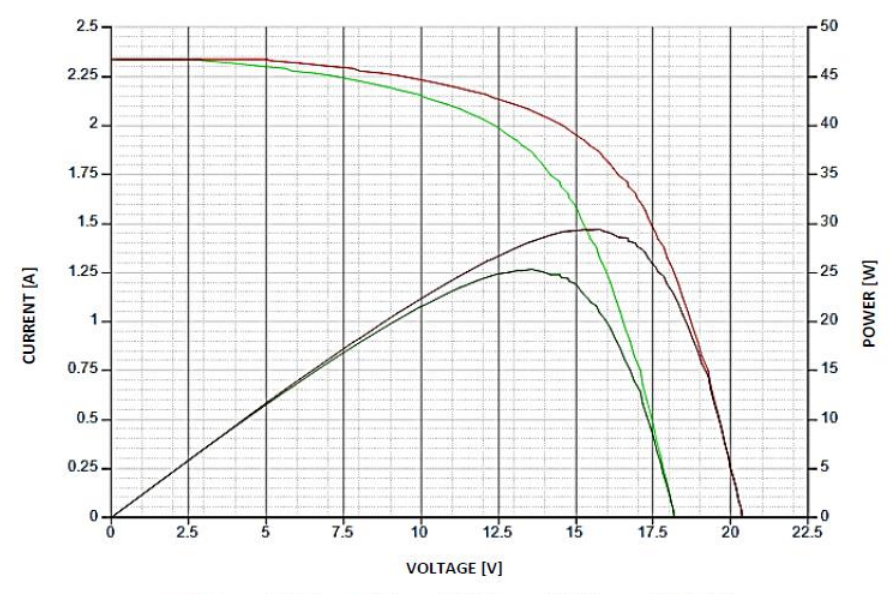

Figure 2: I-V curve for module 2.

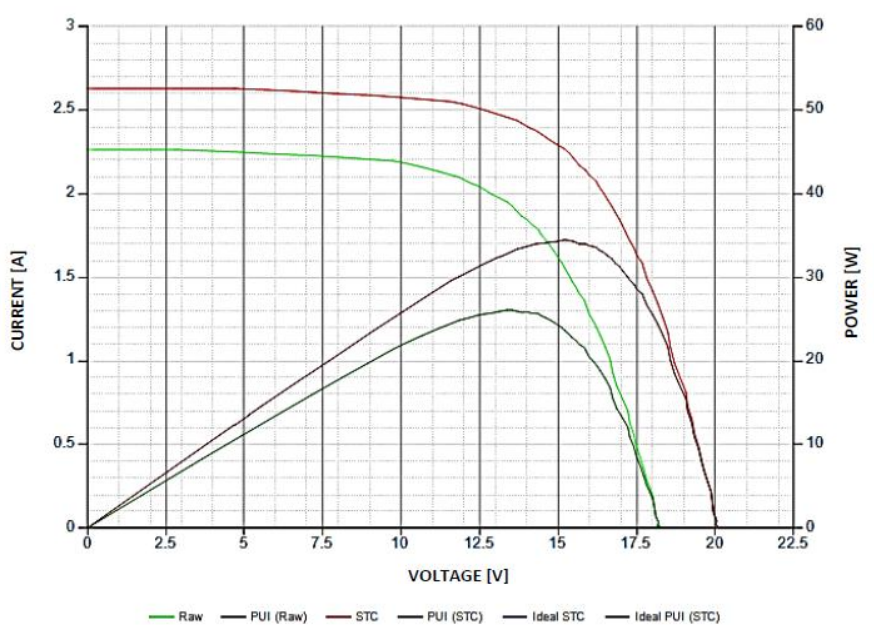

Figure 3: I-V curve for module 3.

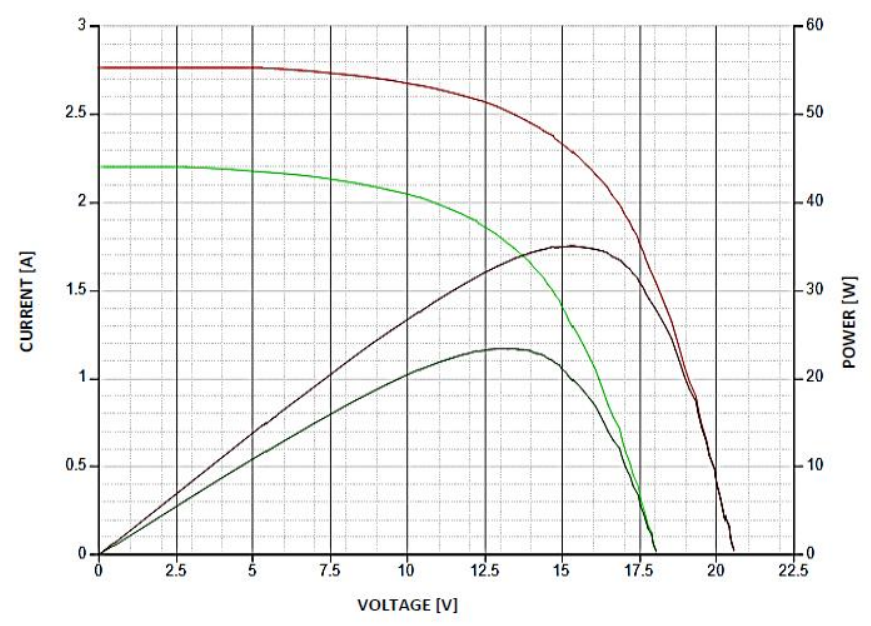

Figure 4: I-V curve for module 4. 
Table 2: I-V tests results at STC.

\begin{tabular}{|c|c|c|c|c|c|c|c|c|}
\hline Nameplate & $\begin{array}{l}\mathbf{P}_{\max } \\
\text { (watts) } \\
\text { 50 }\end{array}$ & $\begin{array}{l}V_{\max } \\
\text { (Volts) } \\
17.2 \\
\end{array}$ & $\begin{array}{l}I_{\max } \\
(A \operatorname{Amps}) \\
2.9\end{array}$ & $\begin{array}{l}\text { V }_{\text {oc }} \\
\text { (Volts) } \\
21.6 \\
\end{array}$ & $\begin{array}{l}\mathbf{I}_{\text {sc }} \\
\text { (Amps) } \\
3.2\end{array}$ & $\begin{array}{l}\text { FF } \\
(\%) \\
\mathbf{7 2} \\
\end{array}$ & $\begin{array}{l}\text { PPF } \\
(\%) \\
100 \\
\end{array}$ & $\begin{array}{l}\text { Efficiency } \\
(\%) \\
\mathbf{1 0 . 7 5} \\
\end{array}$ \\
\hline Module \# & & & & & & & & \\
\hline M1 & 30.88 & 13.59 & 2.27 & 20.50 & 2.8 & 54 & 61.8 & 6.64 \\
\hline M2 & 34.41 & 15.77 & 2.40 & 20.37 & 2.8 & 66 & 68.8 & 7.40 \\
\hline M3 & 34.49 & 15.20 & 2.27 & 20.04 & 2.6 & 66 & 69.0 & 7.42 \\
\hline M4 & 35.42 & 15.31 & 2.29 & 20.53 & 2.8 & 61 & 70.8 & 7.62 \\
\hline M5 & 38.26 & 15.23 & 2.51 & 20.64 & 2.9 & 64 & 76.5 & 8.22 \\
\hline M6 & 35.06 & 15.31 & 2.29 & 20.53 & 2.8 & 61 & 70.1 & 7.54 \\
\hline M7 & 37.04 & 15.89 & 2.33 & 20.82 & 2.8 & 64 & 74.1 & 7.97 \\
\hline M8 & 33.26 & 15.85 & 2.32 & 20.78 & 2.8 & 63 & 66.5 & 7.15 \\
\hline М9 & 32.86 & 15.20 & 2.27 & 20.04 & 2.6 & 66 & 65.8 & 7.07 \\
\hline M10 & 34.09 & 15.60 & 2.19 & 20.44 & 2.6 & 64 & 68.2 & 7.33 \\
\hline M11 & 34.91 & 15.46 & 2.56 & 20.18 & 2.7 & 62 & 70.0 & 7.51 \\
\hline M12 & 34.36 & 15.59 & 2.20 & 20.19 & 2.8 & 61 & 68.7 & 7.38 \\
\hline M13 & 36.42 & 16.13 & 2.17 & 20.49 & 2.7 & 63 & 72.8 & 7.83 \\
\hline M14 & 35.39 & 16.00 & 2.21 & 20.58 & 2.7 & 64 & 70.8 & 7.61 \\
\hline
\end{tabular}

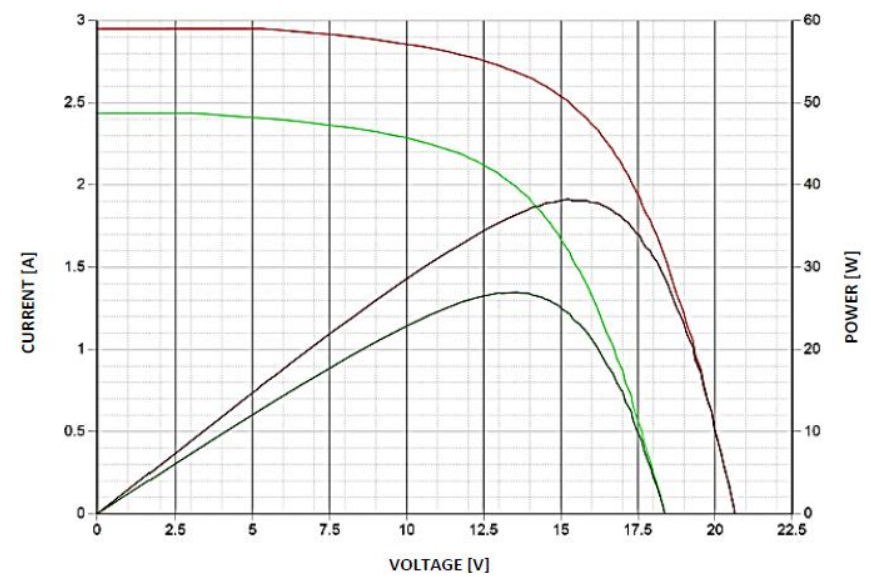

Figure 5: I-V curve for module 5.

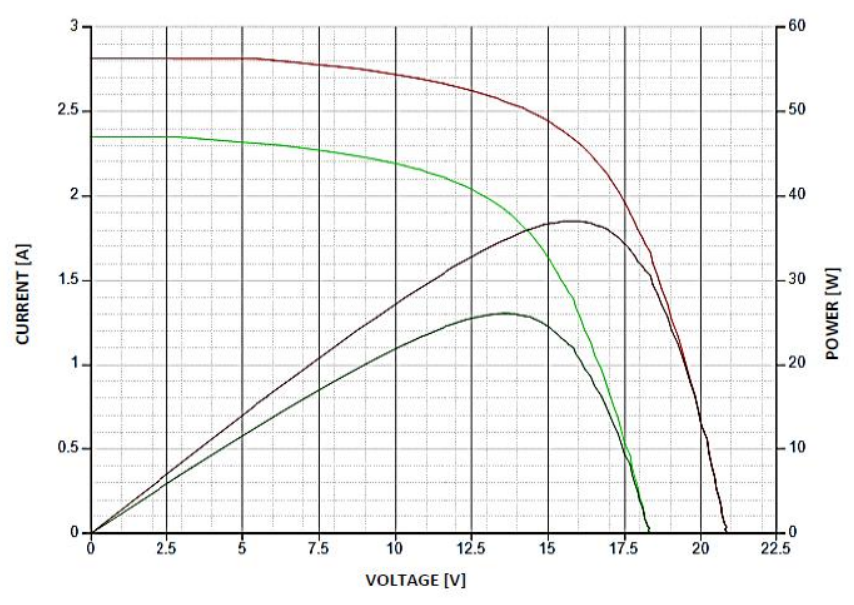

Figure 7: I-V curve for module 7.

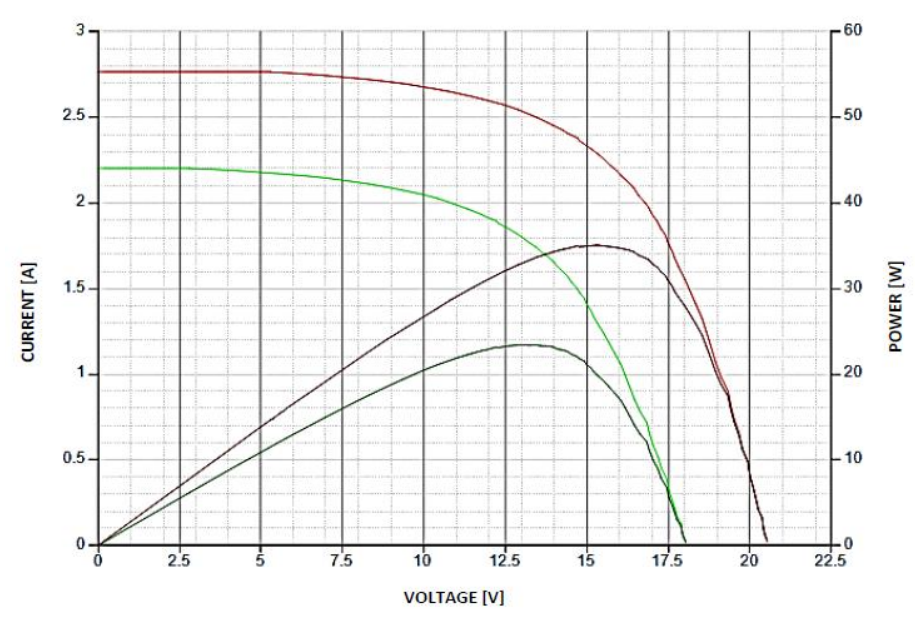

Figure 6: I-V curve for module 6.

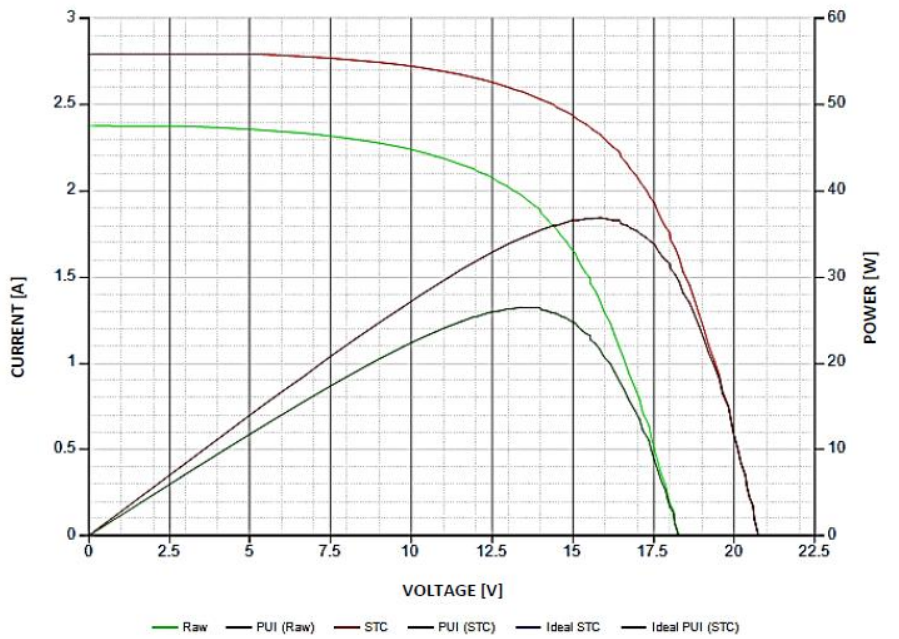

Figure 8: I-V curve for module 8. 


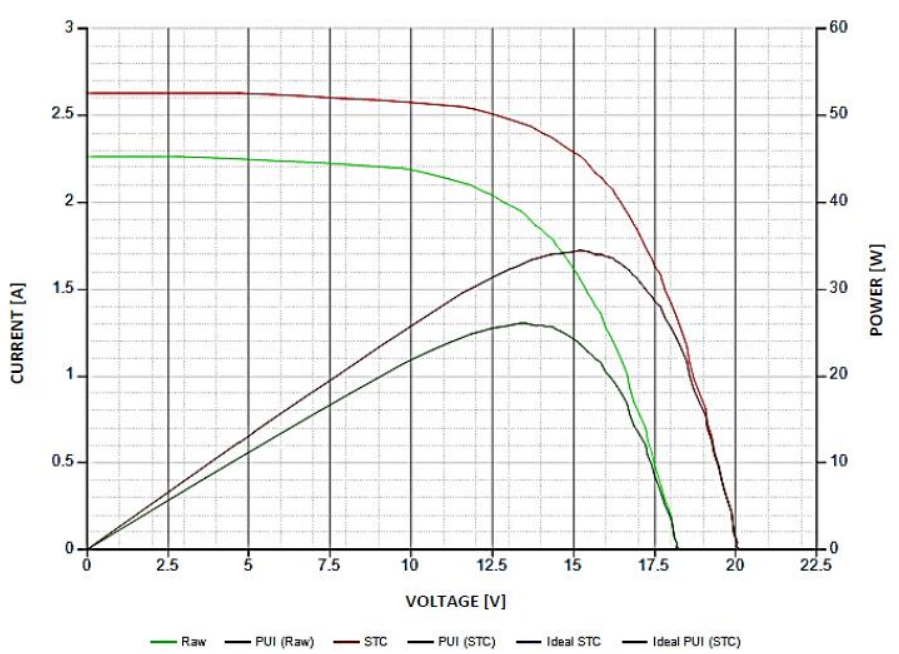

Figure 9: I-V curve for module 9.

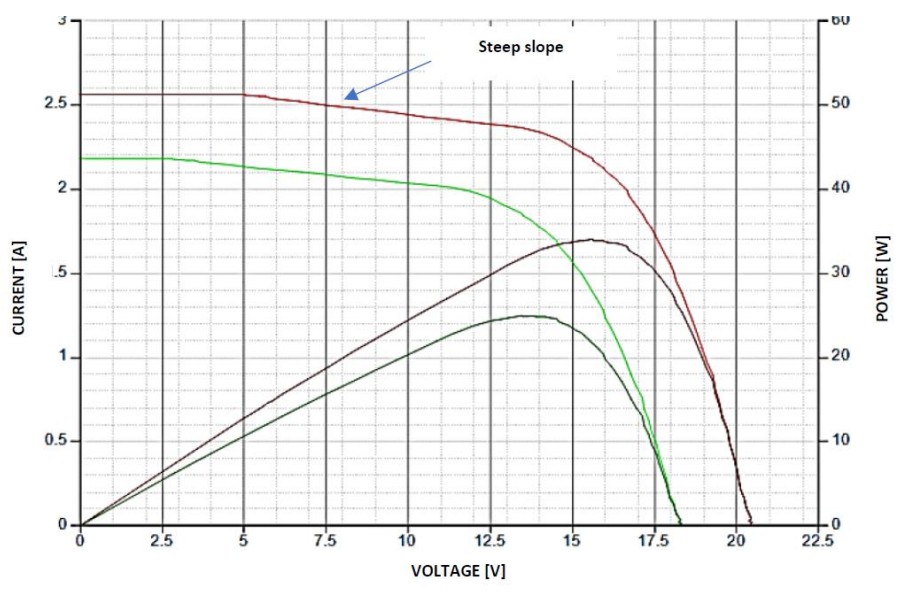

Figure 10: I-V curve for module 10.

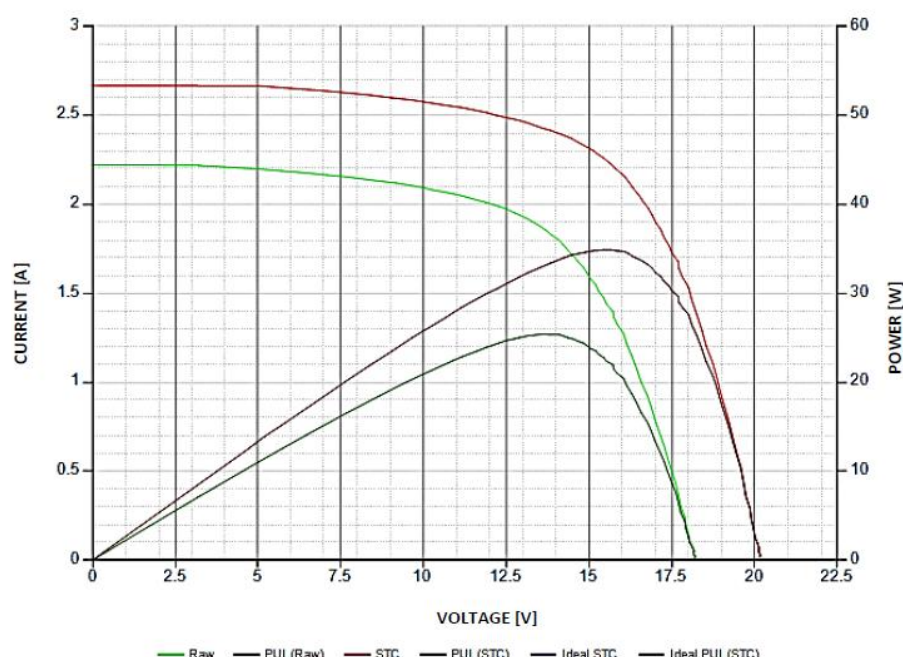

Figure 11: I-V curve for module 11.

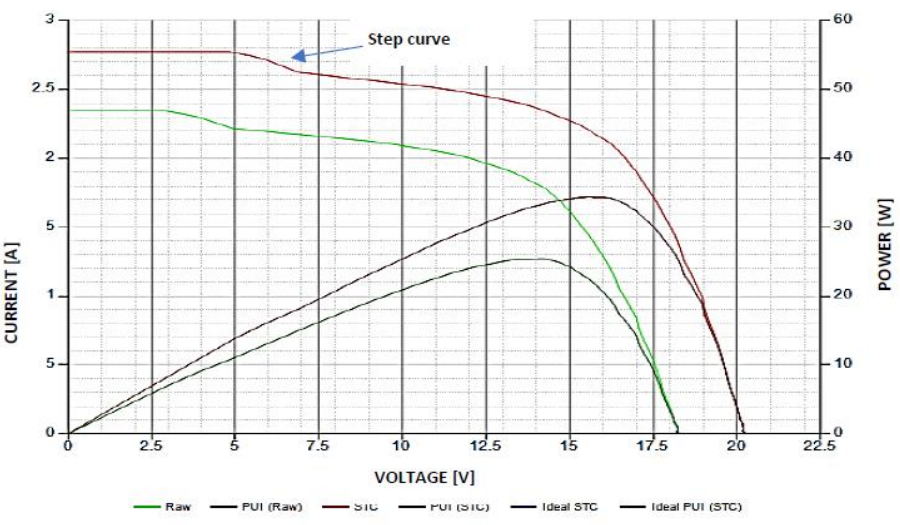

Figure 12: I-V curve for module 12.

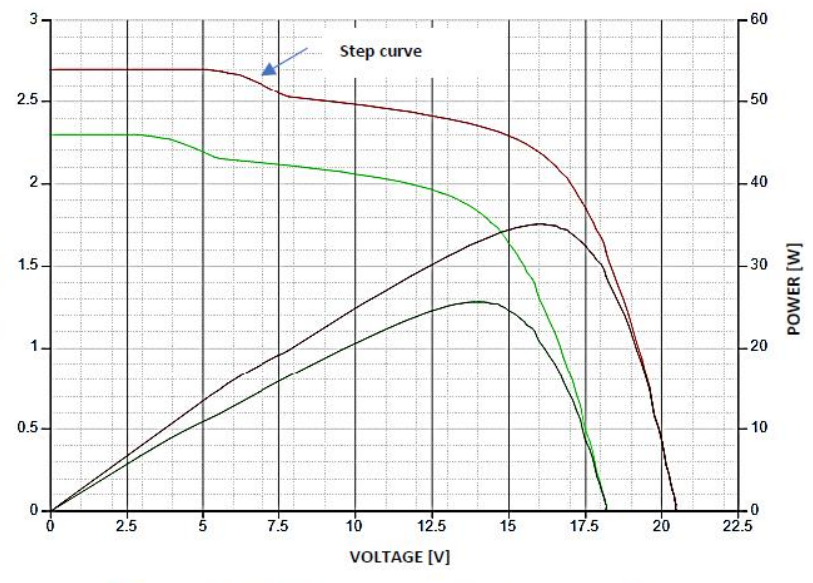

Figure 13: I-V curve for module 13.

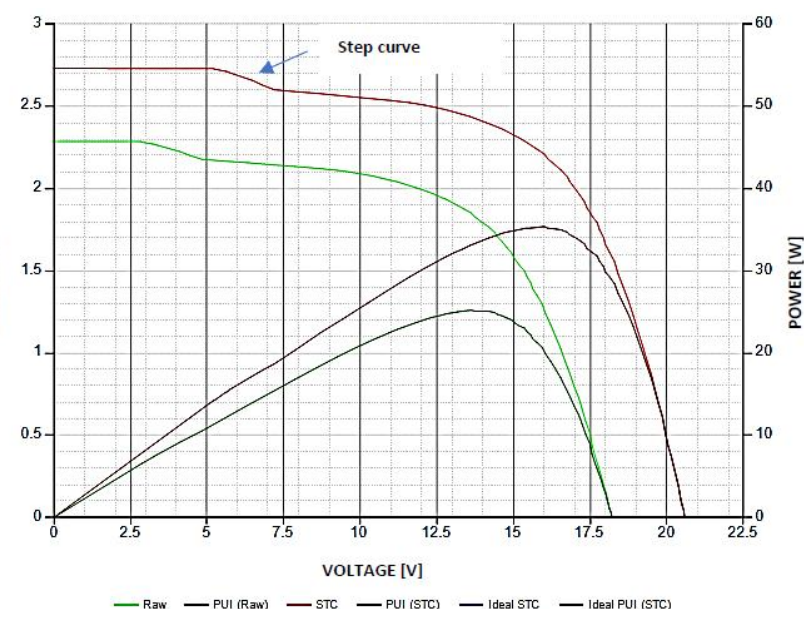

Figure 14: I-V curve for module 14.

\subsection{Visual Inspection}

The results of the visual inspection conducted on module 1 (M1) shows deposits of dust on the surface and sides with minor cell discoloration at the bottom left corner. There was no damage on the front glass and no metallization browning was observed (the busbars and gridlines appeared to 
Table 3: Infra-red imaging data and I-V performance parameters.

\begin{tabular}{|c|c|c|c|c|c|c|c|}
\hline $\begin{array}{l}\text { Module } \\
\text { Number }\end{array}$ & $\begin{array}{l}\operatorname{Max} . \\
\operatorname{temp}\left({ }^{\circ} \mathrm{C}\right)\end{array}$ & $\begin{array}{l}\text { Min. } \\
\text { temp }\left({ }^{\circ} \mathrm{C}\right)\end{array}$ & $\begin{array}{l}\text { Difference } \\
\left({ }^{\circ} \mathrm{C}\right)\end{array}$ & $\begin{array}{l}\mathbf{P}_{\text {drop }} \\
\text { (Watts) }\end{array}$ & $\begin{array}{l}\mathbf{P}_{\text {deg }} \\
\text { (\%/year) }\end{array}$ & $\begin{array}{l}\mathbf{I}_{\mathbf{s c}_{\mathbf{d e g}}} \\
(\% / \text { year })\end{array}$ & $\begin{array}{c}\mathbf{V}_{\mathbf{o c}_{\text {deg }}} \\
\text { (\%/year) }\end{array}$ \\
\hline 1 & 67 & 42 & 25 & 38 & 1.74 & 0.61 & 0.24 \\
\hline 2 & 58 & 47 & 11 & 31 & 1.42 & 0.63 & 0.26 \\
\hline 3 & 58 & 45 & 13 & 31 & 1.41 & 0.58 & 0.32 \\
\hline 4 & 60 & 52 & 8 & 29 & 1.32 & 0.62 & 0.23 \\
\hline 5 & 61 & 50 & 11 & 23 & 1.07 & 0.61 & 0.20 \\
\hline 6 & 61 & 49 & 12 & 29 & 1.36 & 0.72 & 0.23 \\
\hline 7 & 61 & 51 & 10 & 25 & 1.18 & 0.65 & 0.16 \\
\hline 8 & 62 & 48 & 14 & 33 & 1.52 & 0.54 & 0.17 \\
\hline 9 & 60 & 50 & 10 & 34 & 1.56 & 0.62 & 0.33 \\
\hline 10 & 59 & 47 & 12 & 32 & 1.45 & 0.56 & 0.24 \\
\hline 11 & 65 & 56 & 9 & 30 & 1.37 & 0.58 & 0.29 \\
\hline 12 & 63 & 52 & 11 & 31 & 1.42 & 0.67 & 0.29 \\
\hline 13 & 62 & 53 & 9 & 29 & 1.23 & 0.64 & 0.23 \\
\hline 14 & 64 & 53 & 11 & 29 & 1.33 & 0.67 & 0.21 \\
\hline
\end{tabular}

be faded slightly). No cell delamination was observed. Modules 3 and 4 had their junction boxes removed.

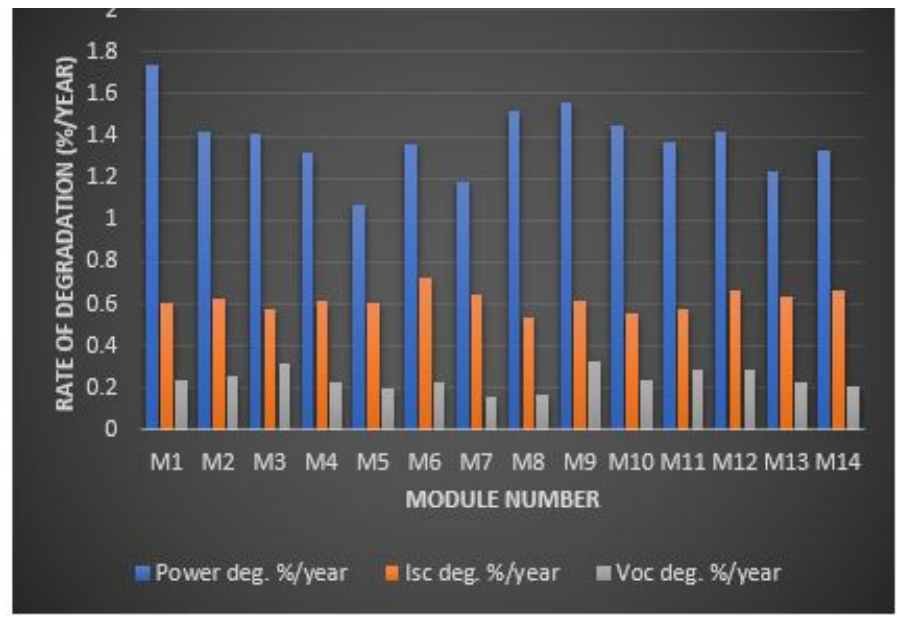

Figure 15: Degradation rates for the fourteen (14) PV modules.

\subsection{I-V Curve Tracing}

Figures 1 through 14 show the I-V plots for the 14 PV modules under study. Figure 1 shows the I-V curve for Module 1 . It shows a steep slope indicating the presence of a series resistance.

Module 1 also yielded the lowest $P_{\max }$ of 30.88 watts, and highest degradation rate of $1.74 \% / \mathrm{yr}$ as shown in Table 2, Table 3 and Fig. 15. This is possibly due to a reduction in power caused by series resistance and shunt resistance. Fig 12, 13 and 14 show the I-V plots for modules 12,13 and 14 respectively. The plots show step curves but no significant reductions in power. Figures 2 through 9 show the plots for modules $2,3,4,5,6,7,8$, and 9 . These plots are normal plots indicating healthy modules according to the interpretations provided by Solmetric [27].

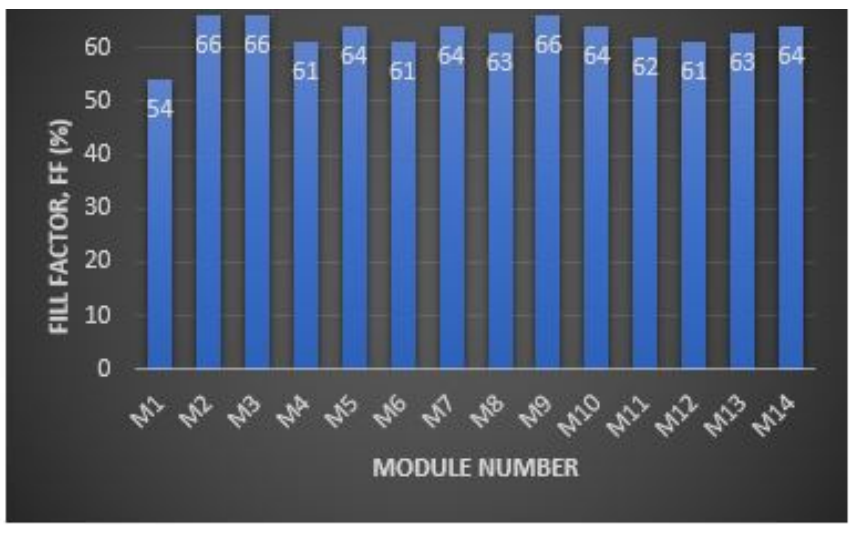

Figure 16: A graph of Fill Factor of all fourteen modules.

Figures 16 through 19 show the plots of FF, efficiency, Isc, Voc and PPF for the 14 modules respectively. Again, Module 1 recorded the lowest values for the FF, efficiency and PPF. This is probably due to the presence of the steep slope caused by series resistance as indicated in reference [28]. Module 1 recorded a PPF of $61.8 \%$ which is lower than the acceptable limit of $80 \%$ for a 25 -years warranty statement issued by most manufacturers as shown in Fig. 19. The I-V plots for each module shows four graphs but six items in the legend. Only the first four were used in this work. These were raw data (green), STC or normalised for the raw data (red), PUI raw (power for the raw data) and PUI STC (STC for the raw power data). The plots for ideal STC and ideal PUI (STC) were not provided by TRISEN in this study. 


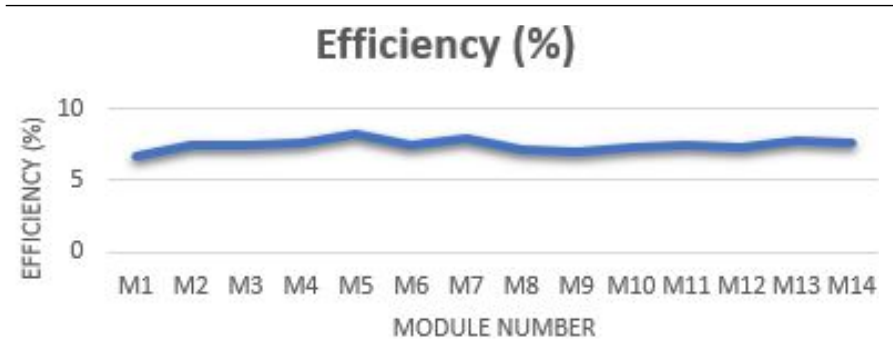

Figure 17: A graph of efficiency of all fourteen (14) modules.

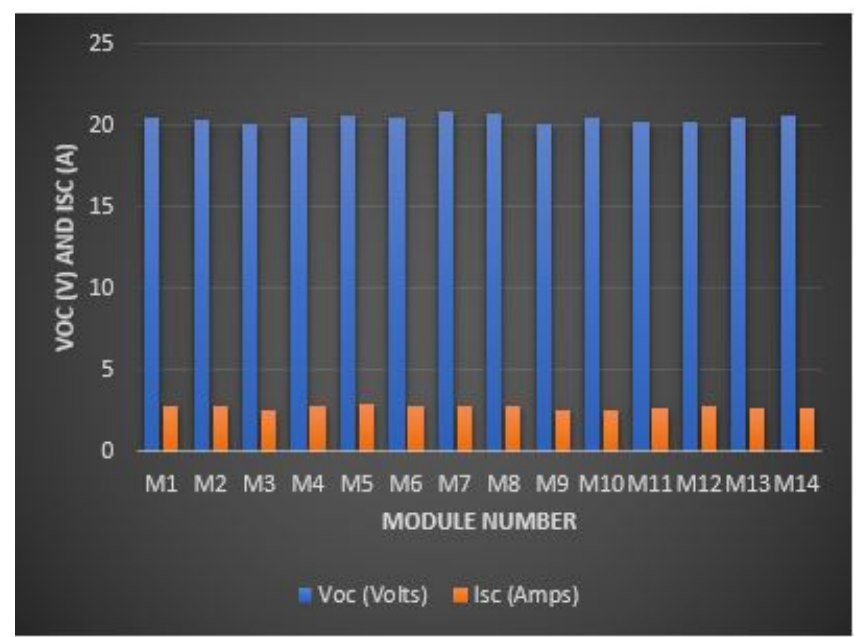

Figure 18: A graph of $V_{o c}$ and $I_{s c}$ of all fourteen modules at STC.

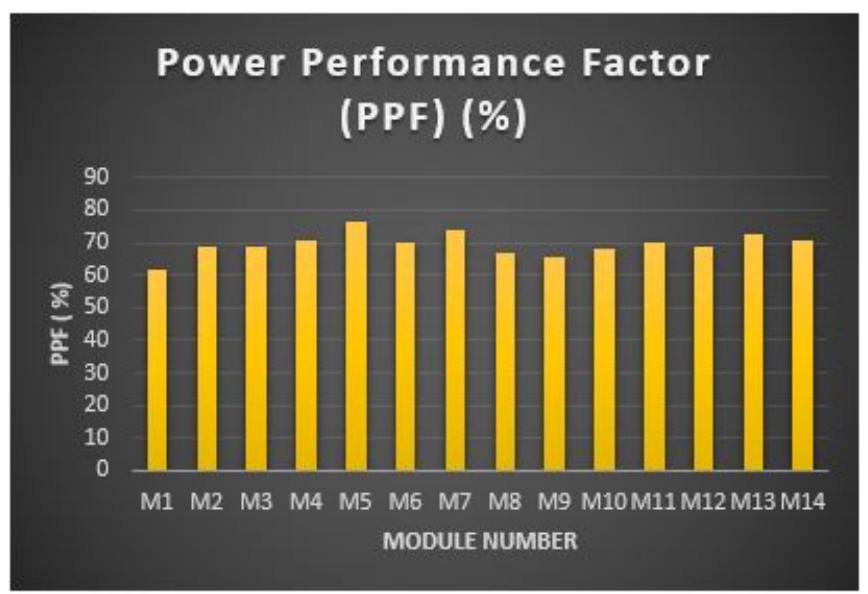

Figure 19: Graph of PPF VS Module Number of fourteen modules.

\subsection{IR Imaging}

Figures 20 through 33 show the IR images for the 14 Modules taken from the field in this study. Figure 20 shows the image of Module 1.0. It shows a hew white colour at the bottom right-hand side of the module, indicating the presence of a hotspot and a failure in the hotspot test. This is confirmed by the high temperature difference of $25^{\circ} \mathrm{C} \mathrm{As}$ indicated previously, temperature difference more than 100 in the hotspot test is an indication of

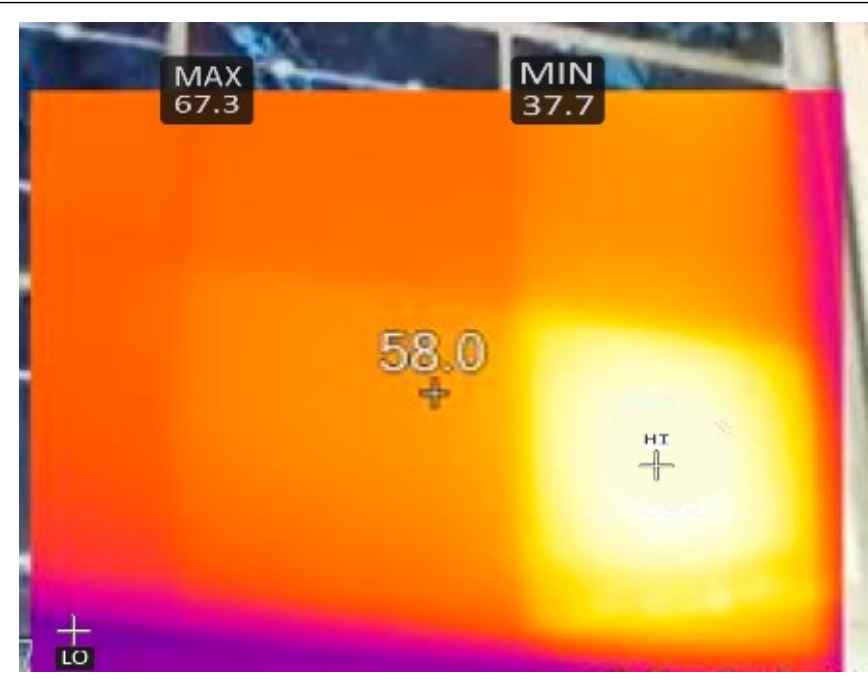

Figure 20: Infrared Image of Module 1. [Source: image from field study]

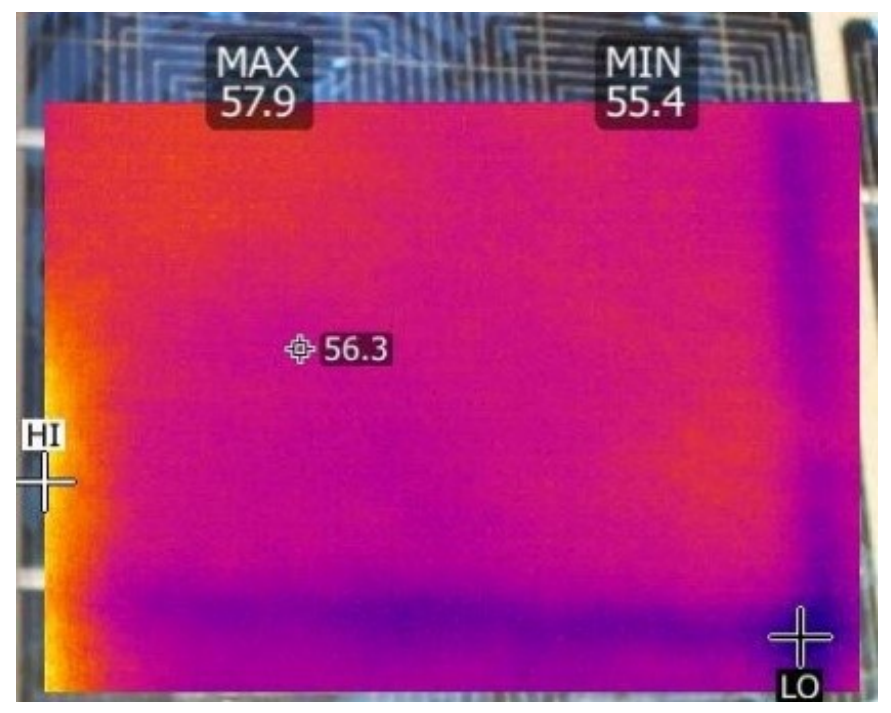

Figure 21: Infrared Image of Module 2. [Source: image from field study]

the presence of a hotspot and a defective cell as indicated in Table 3 which is consistent with the $\mathrm{I}-\mathrm{V}$ data in terms of the lowest Pmax recorded and high degradation rate of $1.74 \% \mathrm{deg} / \mathrm{yr}$. As indicated previously, temperature difference more than $10^{\circ} \mathrm{C}$ in the hotspot test is an indication of the presence of defective cell. Figures 21 through 33 show the IR plots for modules 2 to 14 . The cells in these modules do not show the hue white colour indicated in figure 20.0 in the case of Module 1. Module 5 recorded the lowest degradation rate of $1.07 \% / y r$, the highest efficiency, the highest PPF and reasonably high $\mathrm{FF}$.

\section{CONCLUSION}

In this research work, a number of analysis techniques have been used to evaluate the outdoor performance of polycrystalline silicon PV modules with 22 years of field exposure in Kumasi in sub-Saharan Africa. The techniques used include visual inspection, I-V tests and infrared 


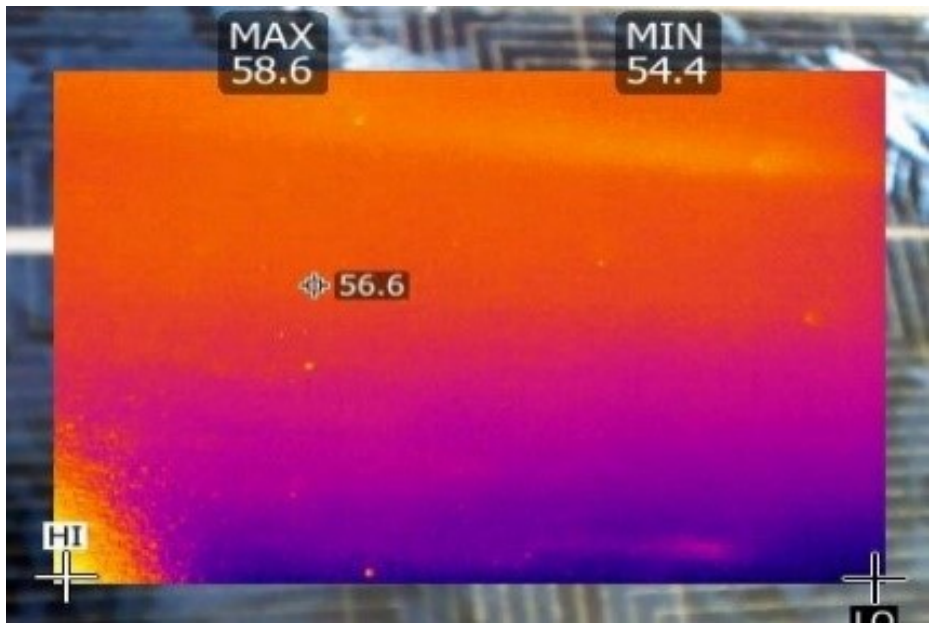

Figure 22: Infrared Image of Module 3. [Source: image from field study]

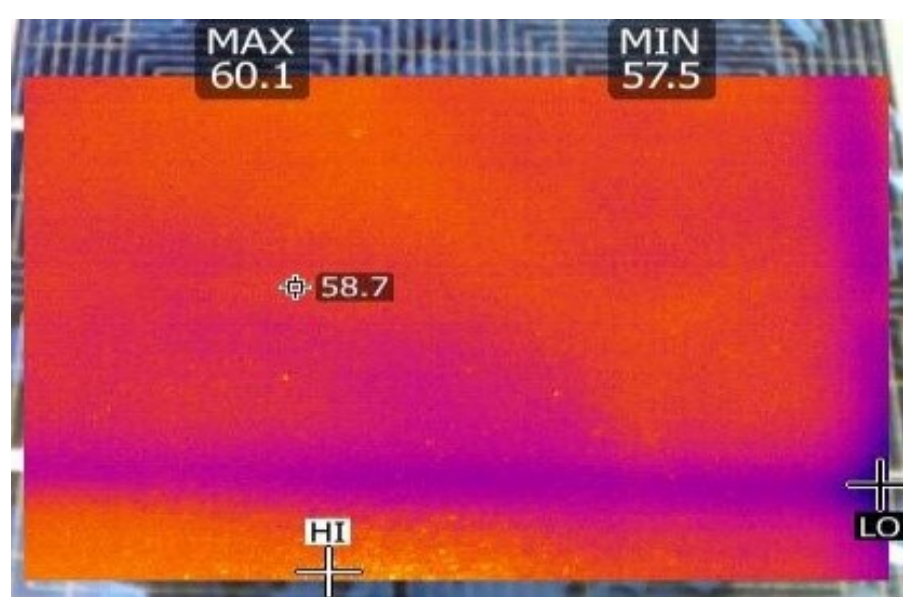

Figure 23: Infrared Image of Module 4. [Source: image from field study]

imaging tests. The rates of degradation were obtained from the I-V data and the results compared with the infrared images. The results showed an average degradation rate of $1.38 \% / y r$ for all 14 modules which is above the acceptable limit of $0.7-1.0 \% / y r$. Module 1 (M1) recorded the highest degradation rate of $1.74 \% / y r$ which is consistent with the IR data which shows a high temperature difference of $25^{\circ} \mathrm{C}$ indicating the presence of hotspots. The I-V curve of M1 also shows a steep slope indicating the presence of a series resistance. This is consistent with the work reported in [28]. The IR image is also in agreement with the temperature difference and I-V data. The IR image shows a hue white colour at the position where the hotspot occurred indicating a defective cell. This observation is in agreement with the high temperature difference of $25^{\circ} \mathrm{C}$. Module 1 also recorded the lowest values for efficiency and fill factor possibly due to the presence of a series resistance. All the 14 modules used in this study recorded PPF below the limit of $80 \%$ for $25-$ year warranty statement issued by most manufacturers. The recorded PPF ranges between 61.8-

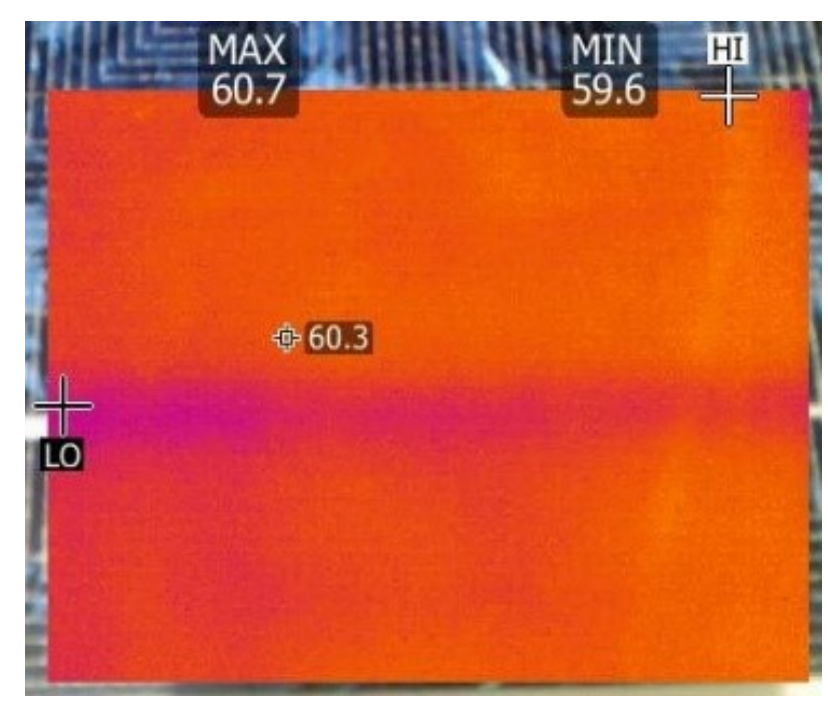

Figure 24: Infrared Image of Module 5. [Source: image from field study]

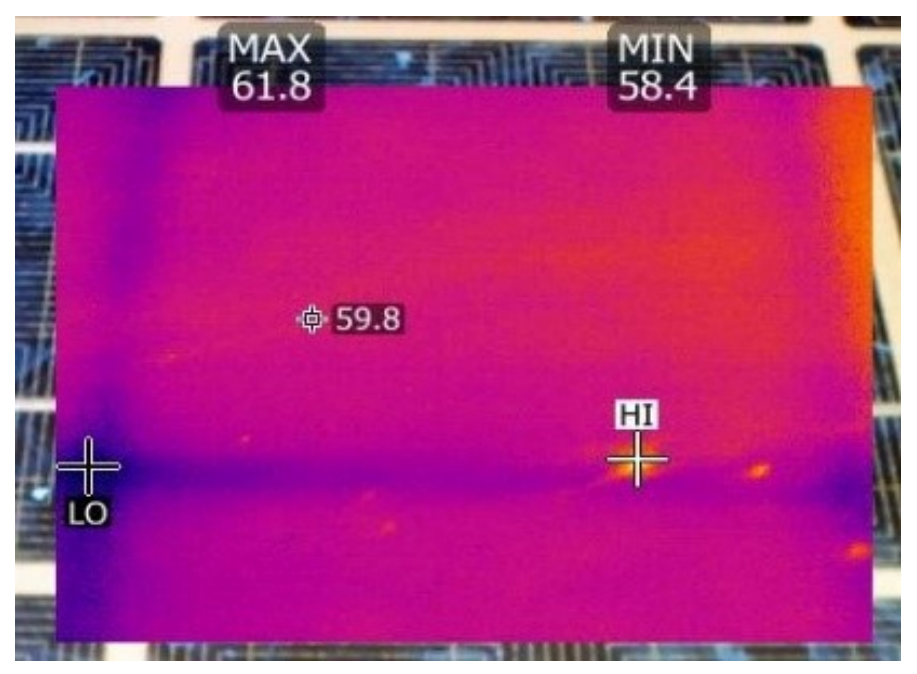

Figure 25: Infrared Image of Module 6. [Source: image from field study]

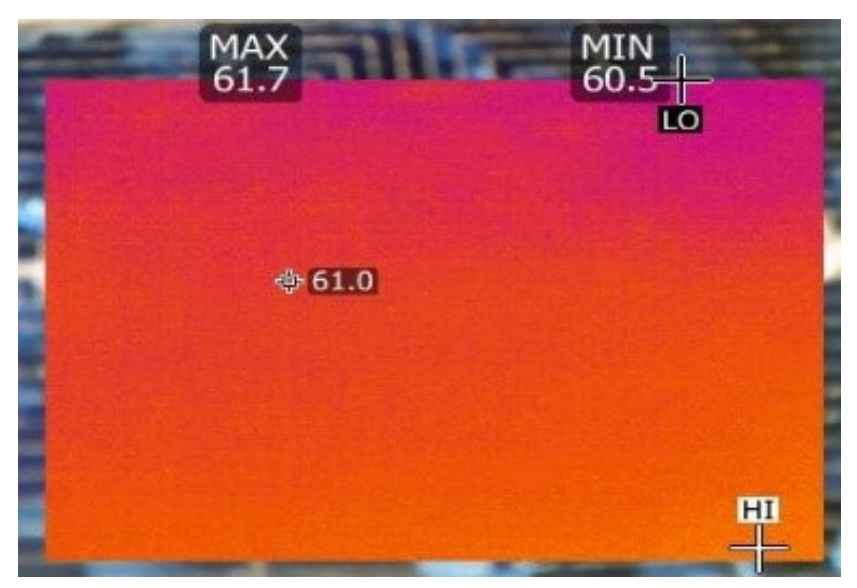

Figure 26: Infrared Image of Module 7. [Source: image from field study] 


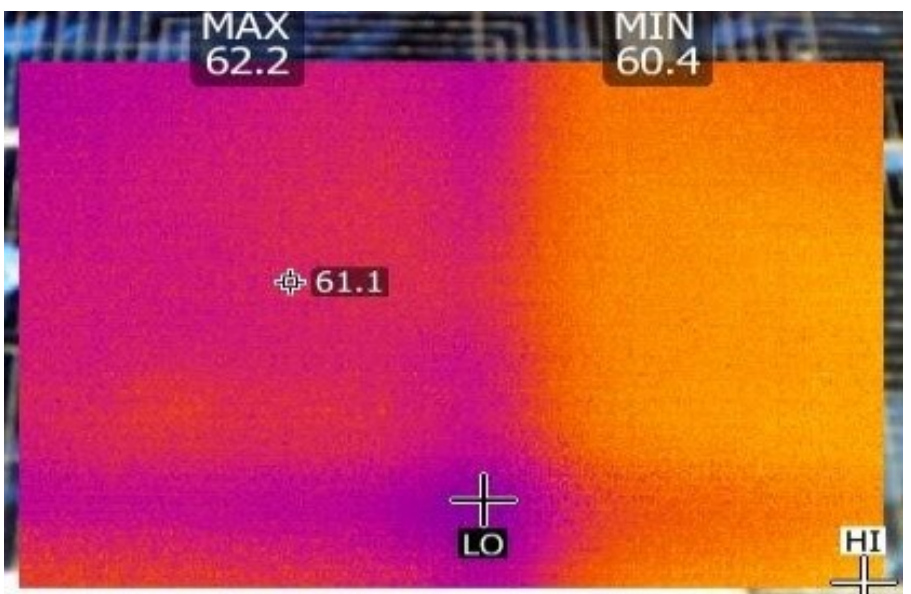

Figure 27: Infrared Image of Module 8. [Source: image from field study]

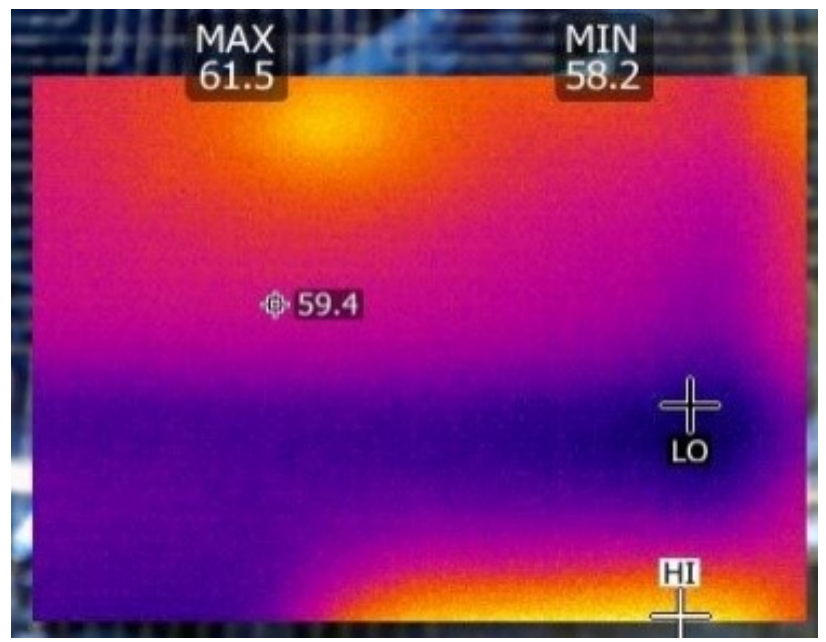

Figure 28: Infrared Image of Module 9. [Source: image from field study]

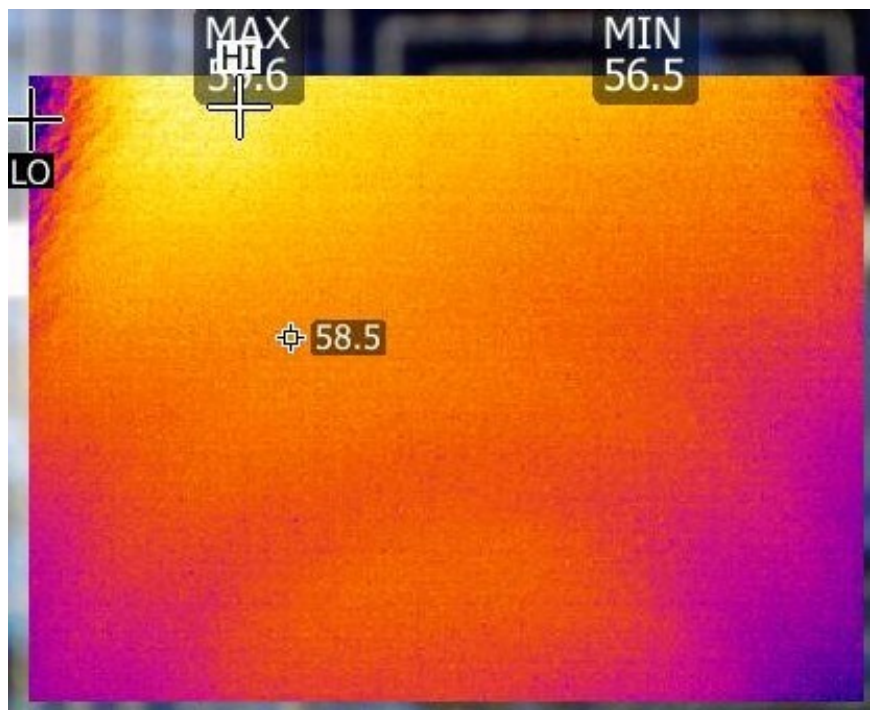

Figure 29: Infrared Image of Module 10. [Source: image from field study]

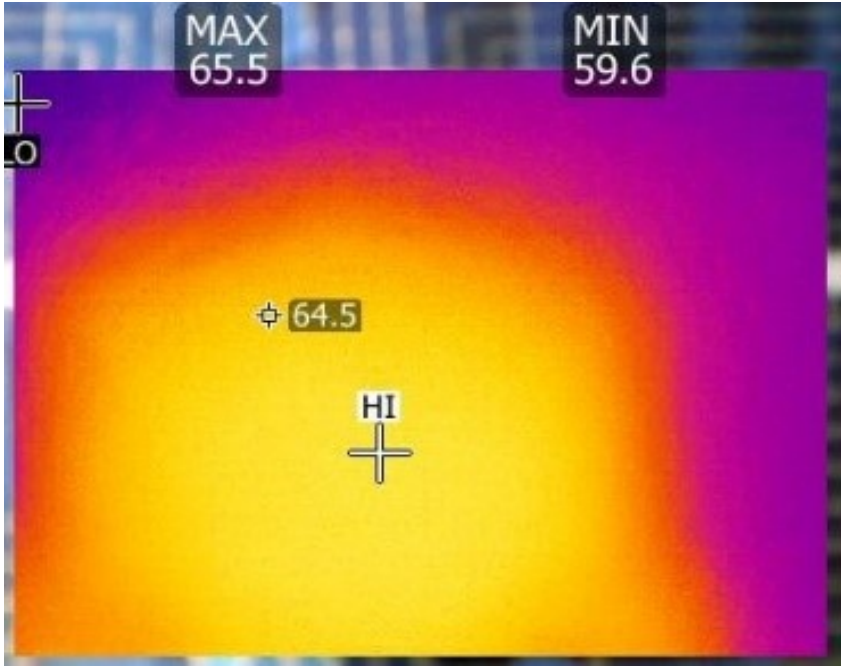

Figure 30: Infrared Image of Module 11. [Source: image from field study]

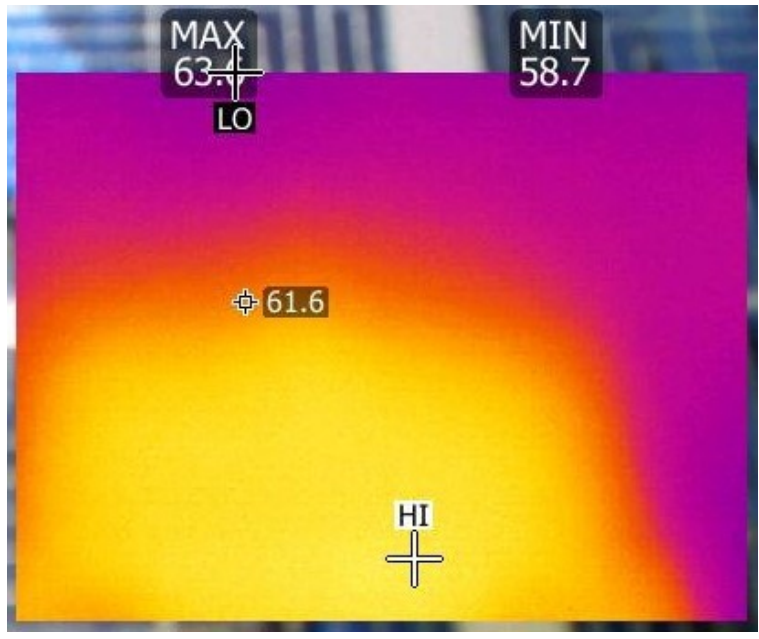

Figure 31: Infrared Image of Module 12. [Source: image from field study]

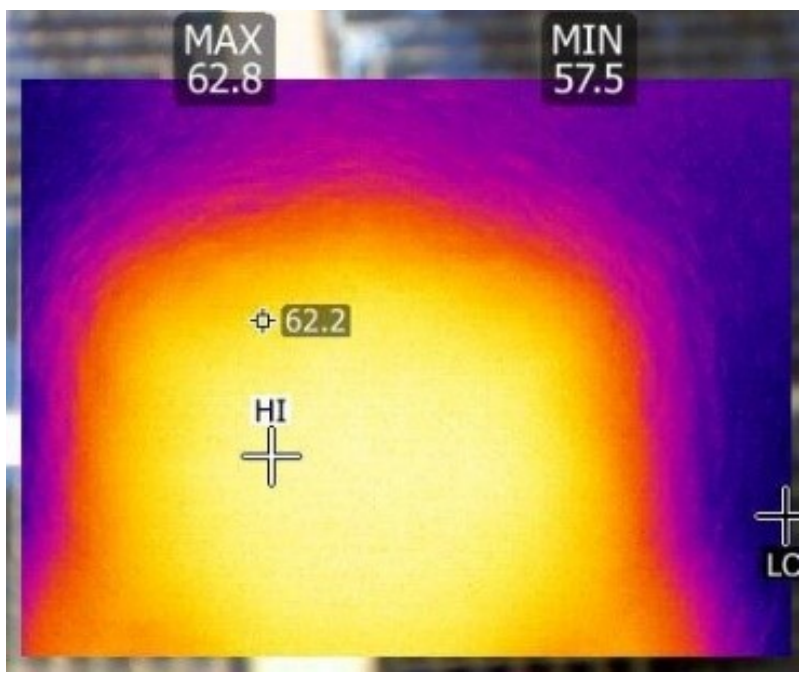

Figure 32: Infrared Image of Module 13. [Source: image from field study] 


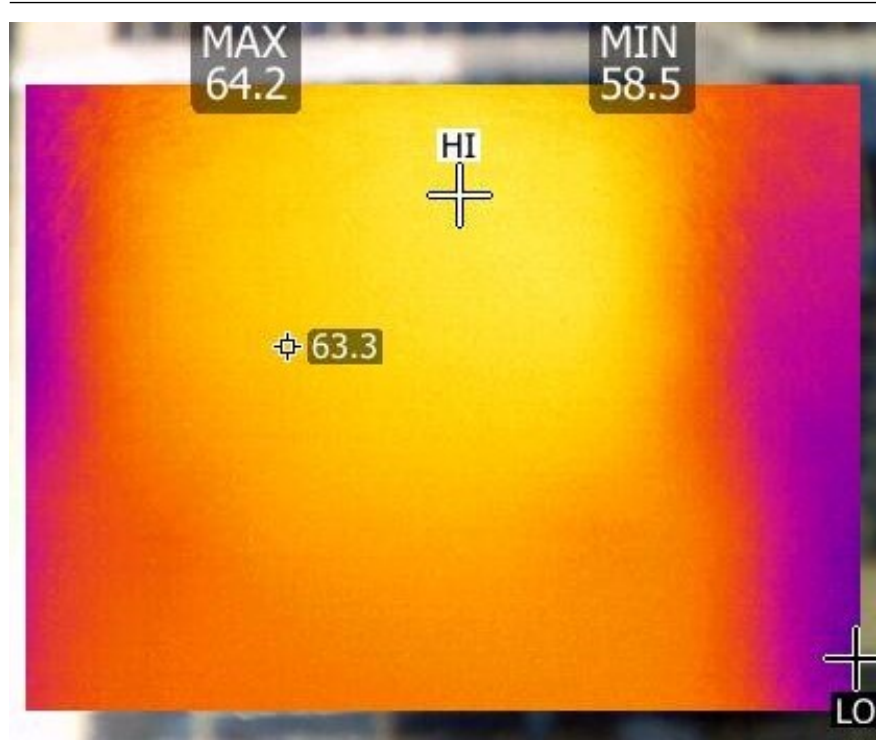

Figure 33: Infrared Image of Module 14. [Source: image from field study]

$76.5 \%$ indicating that the modules have degraded and are therefore recording significant drops in power.

Further work on gaining deeper understanding with regards to the reasons for the high rates of degradation will be carried out as well as actions to address the reasons. This will add more scientific value to the work. Finally, the modules will be tested multiple times throughout the year at specified intervals for more reliable results.

\section{ACKNOWLEDEGMENT}

The author would like to express profound appreciation for the financial support provided by USAID for the PRESSA project Sub-Grant no. 2000004829 through the US National Academy of Sciences.

\section{References}

[1] "National renewable energy laboratory [nrel]," Analysis of photovoltaic system energy performance evaluation method, 2013, nREL: Lakewood, CO, SA.

[2] IRENA, "Renewable energy and jobs-annual report," 2019, iSBN 978-92-9260-134-8.

[3] G. Tiwari and S. Dubey, Fundamental of photovoltaic modules and their applicatios, ser. 2. Royal Society of Chemistry, 2010.

[4] C. Bhalchandra and Y. Sadawarte, "The factors affecting the performance of solar cell," in International conference on Quality upgrading in Engineering, Science and Technology, 2015.

[5] A. Ndiaye, C. Abde'rafi, A. Kobi, M. Cheikh, M. Ke'be', P. A.N., and V. Sambou, "Degradations of silicon photovoltaic modules: A literature review," Solar Energy, vol. 96, pp. $140-151,2013$.

[6] E. Roumpakias, F. Bouroutzikas, and A. Stamatelos, "On-site inspection of PV Panels, Aided by Infrared Thermography," Advances in Applied Science, vol. 1, pp. $53-62,2016$.

[7] H. Bin-Juine, H. Yin-Chen, C. Guan-Yu, H. Po-Chien, and L. Kang, "Improving Solar PV System Efficiency Using One-Axis 3-Position Sun Tracking," Energy Procedia, vol. 33, pp. 280-287, 2013.

[8] Y. K. and G. Yoshida, "Exceeding conversion efficiency of $26 \%$ by heterojunction interdigitated back contact," Solar Energy Materials and Solar Cells, vol. 173, pp. $37-42,2017$.
[9] M. Kacira, M. Simsek, Y. Babur, and S. Demirkol, "Determining optimum tilt angles and orientations of photovoltaic panels in Sanliurfa, Turkey," Renewable Energy, vol. 29, pp. 1265-1275, 2004.

[10] M. Abu-Khader, O. Badran, and S. Abdallah, "Evaluating multi-axes sun-tracking system at different modes of operation in Jordan," Renewable and Sustainable Energy Reviews, vol. 12, pp. 864-873, 2008.

[11] D. Quansah, S. Muyiwa, and L. Mensah, "Solar Photovoltaics in sub-Saharan Africa - Addressing Barriers, Unlocking Potential," in 1st Energy Economics Iberian Conference, EEIC. ' Lisbon, Portugal: APEEN, February 2016.

[12] D. Quansah and S. Muyiwa, "Comparative study of performance degradation in poly- and mono-crystalline-Si solar PV modules deployed in different applications," vol. 43, no. 6, pp. 3092-3109, February 2018.

[13] H. Njoku, K. Ifediora, P. Ozor, and J. Dzah, "Typical performance Reductions in PV modules subject to soiling in a tropical climate," Nigerian journal of technology, vol. 39, no. 4, pp. 1158-1168, October 2020.

[14] A. Salim, F. Huraib, and N. Eugenio, "PV power-study of system options and optimization," in EC photovoltaic solar conference, vol. 8, 1988, pp. 688-692.

[15] T. Ale and K. Rotinpin, "Cooling effects on photovoltaic module performance in the tropical region," Nigerian journal of technology, vol. 38, no. 3, 2019.

[16] C. Zimmerman, "Time dependent degradation of photovoltaic modules by ultraviolet light," Applied Physics Letter 92, 241110, 2008.

[17] O. Babatunde, L. Ehwerhemuepha, C. Nna, and O. Adegbenro, "Efficiency measurement of a photovoltaic system," Nigerian Journal of Solar Energy, vol. 23 , pp. $70-76,2012$.

[18] R. Pramod, G. Tiwari, O. Sastry, B. Birinchi, and S. Vikrant, "Degradation of monocrystalline photovoltaic modules after 22 years of outdoor exposure in the composite climate of india," Solar Energy, vol. 135, pp. 786-795, 2016.

[19] N. Ababacar, C. Abdérafi, K. Abdessamad, M. Cheikh, A. Pape, and S. Vincent, "Degradations of silicon photovoltaic modules: A literature review," Solar Energy, vol. 96, pp. 140-151, 2013.

[20] G. Tamizhmani and J. Kuitche, "Accelerated lifetime testing of photovoltaic modules. solar america board for codes and standards," Photovoltaic Reliability Laboratory. Arizona State University, 2013.

[21] N. Park, J. Joeng, B. Kang, and D. Kim, "The effect of encapsulant discoloration and delamination on the electrical characteristics of photovoltaic module," Microelectronic Reliability, vol. 53, pp. 1818-1822, 2013.

[22] A. Skoczek, T. Sample, and E. Dunlop, "The results of performance measurements of field-aged crystalline silicon photovoltaic modules," Progress in Photovoltaics: Research and Applications, vol. 17, pp. 227-240, 2009.

[23] E. Rodrigues, R. Melicio, V. Mendes, and J. Catalao, "Simulation of a solar cell considering single diode equivalent circuit model," Renewable Energies and Power Quality Journal, vol. 1, no. 9, pp. 369-373, 2011.

[24] (2016, September) Pv education. solar cell structure. [Online]. Available: http://www.PVeducation.org/ pvcdrom/solar-cell-structure

[25] U. Hoyer, "Analysis of pv modules by electroluminescence and ir thermography," in Proceedings of the 24 European Photovoltaic Solar Energy Conference, Hamburg, Germany, September 2009.

[26] G. Acciani, O. Falcone, and S. Vergura, "Typical defects of pv cells," in Proceedings of the IEEE International Symposium on Industrial Electronics, Bari, Italy, September 2009, pp. 4-7.

[27] G. Tamizhmani and J. Kuitche, "Solmetric guide to interpreting i-v curves measurements of pv arrays," Solmetric: Sebastopol, CA, USA, 2011.

[28] T. Abhishiktha, "Effect of Series Resistance Increase on Fill Factor of PV Cells Extracted from Field Aged Modules of Different Climates," Master's thesis, Arizona State University, 2016. 